\title{
German Journal on Artificial Intelligence
}

\author{
Klaus-Dieter Althoff
}

Published online: 3 April 2013

(C) Springer-Verlag Berlin Heidelberg 2013

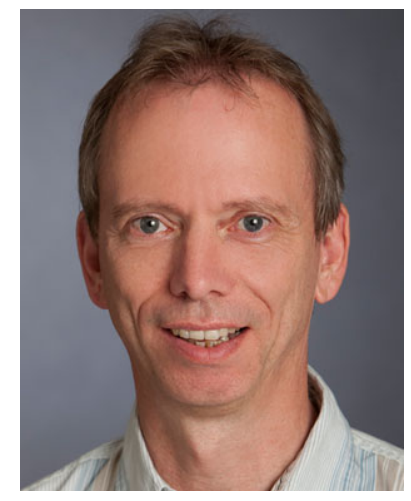

Liebe Leserinnen, liebe Leser,

mit dem vorliegenden Heft erscheint die 14. Ausgabe der KI-Zeitschrift im Springer Verlag. Ich darf Ihnen mitteilen, dass seitens des Springer Verlages die Herausgabe der KIZeitschrift als sehr positiv bewertet wird. So gab es knapp 10.000 Downloads im Jahre 2012 (nach ca. 3.500 im Jahr 2010 und ca. 8.800 in Jahr 2011). 56 \% dieser Downloads sind nicht aus Deutschland und $44 \%$ der Downloads nicht aus Europa, so sind z.B. ca. $22 \%$ der Downloads aus China und $9 \%$ aus Nordamerika. Wir können also festhalten, dass die KI-Zeitschrift nicht nur einen englischen Untertitel sowie englische Bezeichnungen für die einzelnen Rubriken hat, der Standardfall englische Artikel sind (deutsche sind weiterhin erlaubt), und drei von neun Herausgebern eine Professur im Ausland haben, sondern dass diese von Uli

K.-D. Althoff $(\bowtie)$

Competence Center Case-Based Reasoning Deutsches

Forschungszentrum für Künstliche Intelligenz, Universität

Hildesheim, Institut für Informatik, Trippstadter Straße 122,

67688 Kaiserslautern, Deutschland

e-mail: Klaus-Dieter.Althoff@dfki.de

Furbach während seiner Zeit als Fachbereichssprecher angestoßene Internationalisierung der KI-Zeitschrift sich zunehmend auch in den Zugriffszahlen widerspiegelt.

Unterstützt wird diese Entwicklung auch durch die Tatsache, dass die Organisation der britischen KI-Wissenschaftler (British Computer Society Specialist Group on Artificial Intelligence: BCS-SGAI), die auf ihrer jährlich stattfindenden Tagung die drei besten Anwendungsbeiträge auszeichnet, die Autoren dieser Beiträge nun regelmäßig auffordern wird, eine überarbeitete Langfassung dieser Beiträge bei der KI-Zeitschrift einzureichen.

Wir würden uns sehr darüber freuen, wenn Sie die KIZeitschrift auch weiterhin unterstützen, z.B. durch Einreichen Ihres Fach- oder Ihres Projektbeitrages oder durch Ihre Bereitschaft eingereichte Beiträge zeitnah zu begutachten. Nach dem Begutachtungsprozess ist die Dauer bis zur Veröffentlichung eines Beitrages als Online First im Tagebereich, auf jeden Fall unter einem Monat. Wir freuen uns darüber, dass wir - wie auch im vorliegenden Heft - immer wieder motivierte anerkannte Wissenschaftlerinnen und Wissenschaftler finden, die bereit sind einen Themenschwerpunkt zu organisieren und qualitativ hochwertige Beiträge für (fast) alle unsere Rubriken einzuwerben.

Ich wünsche Ihnen viel Spaß beim Lesen der Beiträge, diesmal mit dem Themenschwerpunkt Symbol Grounding, der von zwei schwedischen und einer deutschen Gastherausgeberin herausgegeben wird.

Und wenn die gelesene Information für Ihre wissenschaftliche Arbeit wichtig ist, dann würden sich sowohl die Autoren als auch die Herausgeber sowie der Verlag über Ihr Referenzieren dieser Beiträge freuen $(:)$

Herzliche Grüße

Klaus-Dieter Althoff 


\section{Forthcoming Special Topics}

\section{Artificial Intelligence in Agriculture}

Besides the three classical production factors land, labor and capital, the factor "information and knowledge" becomes more and more important. This specifically holds for the agricultural domain because we are faced to the challenge that we have to double the crop yields until 2050 to feed the expended 9 Billion of people worldwide. Since the amount of arable land in developed countries is shrinking we have to concentrate on the better employment of knowledge and technology. This way, GPS with its area-wide spatial reference service already enabled a new dimension to the optimization of production processes in crop farming. In addition, first approaches of a standardized IT-infrastructure realize a promising basis to exploit the growing availability of geospatial information, reliable weather forecasts, soil quality records, status reports about plants, tips for yield optimization and environmental protection towards a better economizing. The Web of Services in combination with mobile networks allows that a future GPS- and sensor-based tractor connects to the wireless sensor network of the present cropland in order to query the current soil moisture and other parameters to optimize upcoming tasks and workflows.

Especially for the Artificial Intelligence, this context reveals a variety of high-potential technologies to be applied, as the agricultural and environmental domains provide a steadily growing pool of publicly accessible knowledge, which is financed and maintained from governmental organizations. Innovative AI technologies can significantly contribute to organize, connect, and further develop this knowledge in order to better supply the collective demand for food.

\section{Guest editor:}

Prof. Dr. Prof. h.c. Andreas Dengel

German Research Center for Artificial Intelligence (DFKI)

Trippstadter Str. 122, D-67663 Kaiserslautern

Phone +49-631-20575-1000

Fax +49-631-20575-1020

Email andreas.dengel@dfki.de

\section{Transfer Learning}

Machine learning research for a long time has focused on tabula rasa approaches, i.e. learning techniques that start from scratch without exploiting the potential of prior experience gained on other tasks. Transfer learning attempts to tap into this potential, viewing learning as a life-long process where everything learned can be used to speed up and improve future learning performance. In this context, past experience can be in terms of the knowledge and skills gained through learning, as well as the learning process itself.

This special issue will cover all aspects of transfer learning, including but not limited to:

- Knowledge, task, and state-space representation

- Inter-task mappings of states and actions

- Source task selection

- Evaluation methods

- Reward shaping

- Meta learning

- Life-long learning

- Applications, e.g. robotics.

We are seeking a wide range of contribution formats for the special issue, e.g. technical articles, surveys, interviews, project descriptions, and lab portraits. To suggest a contribution, please contact as soon as possible:

\author{
Dr. Daniel Kudenko \\ Department of Computer Science \\ University of York \\ York, YO105GH \\ United Kingdom \\ kudenko@cs.york.ac.uk
}

\section{Space Robotics}

While Space Exploration may be considered anything but dull, it certainly is very dangerous. Expanding our knowledge on the solar system to look for clues to such fundamental questions as the origins of life, or a sustained human presence on anything other than earth may well be worth the risk. The involved costs for mitigating the risk of human space flight are prohibitive. Robotic missions, like the hugely successful Mars Exploration Rovers, have shown that Robotics as a sub-field of Artificial Intelligence can perform scientific exploration activities without human presence, and will play an even more prominent role in future mission scenarios. World wide technology research efforts are continuously expanding the capabilities of mobile robotic systems. This special issue on "Space Robotics" of the Künstliche Intelligenz Journal seeks to present a collection of research efforts, industry activities and other insights into this hugely interesting and versatile field of AI.

The topics of interest include, but are not limited to:

- Exploration systems and technologies

- Orbital servicing

- Human mission support

- Operations support

- System design/architecture/behavior 
The Künstliche Intelligenz Journal, which is published and indexed by Springer, supports the following lists of formats: Technical contributions, research projects, discussions, dissertation abstracts, conference reports and book reviews.

If you are interested in contributing to this special issue, please contact one of the guest editors:

Jakob Schwendner

Robotics Innovation Center

Deutsches Forschungszentrum für Künstliche Intelligenz (DFKI)

28359 Bremen, Deutschland

jakob.schwendner@dfki.de
Prof. Frank Kirchner

Robotics Innovation Center

Deutsches Forschungszentrum für Künstliche Intelligenz (DFKI)

28359 Bremen, Deutschland

frank.kirchner@dfki.de

Bernd Sommer

Deutschen Zentrums für Luft- und Raumfahrt (DLR)

Königswintererstrasse 522-524

53227 Bonn, Deutschland

Bernd.Sommer@dlr.de 